\title{
Management Fusarium wilt of sweet pepper by Bacillus strains
}

\author{
Abada K. A., M. A. Ahmed \\ Plant Pathol. Dept., Fac. Agric.,Cairo Univ. Giza, Egypt \\ Email address: \\ dr_khairy_abada@yahoo.com (Abada K. A.)
}

\section{To cite this article:}

Abada K. A., M. A. Ahmed. Management Fusarium Wilt of Sweet Pepper by Bacillus Strains. American Journal of Life Sciences. Special Issue: Role of Combination between Bioagents and Solarization on Management of Crown-and Stem-Rot of Egyptian Clover. Vol. 2, No. 6-2, 2014, pp. 19-25. doi: 10.11648/j.ajls.s.2014020602.13

\begin{abstract}
Isolation trials from the roots of wilted sweet pepper plants yielded Alternaria spp., Fusarium oxysporum, Pythium spp., Rhizontonia solani, Sclerotium rolfsii and Trichoderma spp. The isolates of the fungus F. oxysporum were selected to test their pathogenicity and Kalubia isolate was the most virulent one. The fungus was virulent to sweet pepper and low infection was found in case of the other five tested plants. Therefore, the fungus F. oxysporum named Fusarium oxysporum f.sp. capsici. All the five Bacillus strains, i.e. Bacillus chitinosporus, B. coagulans, B. humilus ,B.subtilis and B. thuringiensis caused significant reduction to the radial growth of F.o.f.sp.capsici compared with control treatment. In addition, the growth of the tested pathogen was completely inhibited by B.subtilis and B.thuringiensis at the concentration of $60 \%$. Furthermore, B.thuringiensis was the most efficient bioagent in this regard followed by B.subtilis then B.pumilus. Adding the three tested bioagents, i.e.B.pumilus .B.subtilis and B. Thuringiensis to soil infested with F.o.f.sp.capsici resulted in significant reduction to sweet pepper wilt with significant increase to the plant height as well as the number of pods and their weight / plant compared with control treatment. The symptoms of the disease were obvious both on the foliage growth and the xylem vesicles, but the severity of the disease was more higher on the xylem vesicles than on the foliage growth. In addition, plants grown in soil infested with Bacillus strains were of high values of plant height and fruit yield (number and weight / plant) than that grown in the control (uninfested soil). The total phenolic compounds were greatly increased in the bacterial treated plants as compared to untreated plants with the bioagents and that infested with the pathogen only. These results give a potential of these bacterial strains for use as plant protection agents against Fusarium wilt of sweet pepper. This work was performed to investigate the potential of some bacterial bioagents, i.e. B. humilus , B.subtilis and B. thuringiensis on management of sweet pepper Fusarium wilt and the formation of phenolic compounds in the plants.
\end{abstract}

Keywords: Bacillus spp,Bioagents, FusariumWilt, Sweet Pepper, Total Phenolic Compounds

\section{Introduction}

Sweet pepper (Capsicum annum L.) is considered one of the most important vegetable crops in Egypt for local consumption and exportation. The economic importance of sweet pepper cultivation in the world could be explained by its high nutritional value of antioxidants, vitamins and some other compound. Therefore, improving the bioproduction of this crop is one of the objectives in agriculture in many countries (Akram et al., 2013).

The total cultivated area with sweet pepper in Egypt in the open field during 2013 growing season reached about 65240 feddan with a total production of 387964 ton at the rate of 5.95 ton /feddan in addition to about 1000 feddan for protected cultivation with a production of about 7500 ton with an average of 7.5 ton / feddan (Food Legume Statics Dept., Field Crops Res. Instit., ARC.,2014).

Sweet pepper is liable to be attack by many bacterial, fungal, viral and nematode diseases as well as physiological disorder. However, Fusarium wilt is considered the major devastative and destructive disease affecting crop production of pepper (Black et al.,1991 and Attia and Abada, 1994 ).

Due to the cultivated area in Egypt is limited, therefore crop rotation is not applied and this caused great difficult, especially in case of specific soil borne pathogens such as 
Fusarium wilt. On the other hand, the use of chemical control against such diseases sometimes gives good results. However, improper use of fungicides leads mostly to environmental pollution, disasters throughout the world and the phenomena of resistance to the plant pathogens (Brewer and Larkin, 2005). Hence, to overcome these difficulties, it is urgent to apply biological control as an alternative safe efficient method against this disease (Akram et al.,2013). Biological control is considered an important approach of agricultural biotechnology in recent years for controlling many fungal plant pathogens (Zaher et al.,2013and Abada and Eid,2014).

Resistance to plant disease is supposed to be a dynamic and multifactorial process. It is assumed that plant defense response can be activated by specific recognition of some microorganisms by the plant. There may be whole organisms or products secreted by microorganisms under the influence of which plants initiate defense response (Albersheim et al., 1975 and 1978 and Akram et al.,2013].

This work was planned to management of Fusarium wilt of sweet pepper by induce systemic resistance by Bacillus spp. Also, phenolic compounds constituent to plant defense was also assayed.

\section{Materials and Methods}

\subsection{Isolation, Purification and Identification of the Associated Fungi}

Sweet pepper plants ( Balady cv.) showing characteristic symptoms of wilt were collected from Dakahlia, Menofia, Kalubia and Giza governorates. The infected root samples were thoroughly washed in running tap water and cut into small pieces with lesion having half healthy and half diseased tissue. The pieces were surface sterilized with $2 \%$ sodium hypochlorite for two minutes. The tissue pieces were subsequently washed in three changes of sterile water to eliminate excess sodium hypochlorite and then the pieces were transferred onto PDA medium in Petri dishes. Plates were incubated at $25 \pm 2{ }^{\circ} \mathrm{C}$ and observed periodically for growth of the fungi. The pure cultures of the isolated fungi were obtained by hyphal tip method and/ or single spore technique and maintained on PDA slants throughout the investigation. The emerged fungi were identified on the basis of cultural, morphological characteristics and the description of Booth (1971) and Domsch et al. (1980).

\subsection{Pathogenicity Test}

The inoculum of $F$. oxysporum was prepared by culturing the fungus on potato dextrose agar (PDA) medium for 5 days in Petri plates. Conidial suspension was prepared by pouring $20 \mathrm{ml}$ of sterile distilled water in each Petri plate. The concentration of conidia was adjusted to $1 \times 10^{3}$ conidia per milliliter using haemocytometer. Pathogenicty test was carried out by two ways:

\subsubsection{Using Seeds}

Sweet pepper seeds (Balady cv.) were surface sterilized with $1.0 \%$ solution of sodium hypochlorite for $1 \mathrm{~min}$ and then thoroughly washed with tap water. Five seeds were sown in each plastic pot $(25 \mathrm{~cm}$. in diameter $)$ contained infested clay soil by spore suspension of any of the four isolates of Fusarirum oxysporum ( $1 \times 10^{3}$ conidia / ml water $)$ at the rate of $50 \mathrm{ml} /$ pot . Also, Five seeds were, also, sown in each plastic pot $(25 \mathrm{~cm}$. in diameter $)$ contained disinfested clay soil and served as control. Five pots were used for each treatment. The plants were thinned into three seedlings / pot one month after sowing and left to grow for four months under greenhouse conditions (Fac. Agric., Cairo Univ.). The plants were examined for the severity of infection by the tested fungus monthly as mentioned under disease assessment and the averages were recorded. The pots were irrigated when it was necessary and fertilized with recommended doses as recommended by Min. of Agric. and Land Reclamation.

\subsubsection{Using Transplants}

Three transplants (Balady cv.) of 35 day-old, grown in disinfested soil, were transplanted in each plastic pot $(25$ $\mathrm{cm}$. in diameter) contained infested clay soil by spore suspension of any of the four isolates of Fusarirum oxysporum $\left(1 \times 10^{3}\right.$ conodia / $\mathrm{ml}$ water $)$ at the rate of $50 \mathrm{ml} /$ pot . Also, Three transplants were, also, transplanted in each plastic pot $(25 \mathrm{~cm}$. in diameter) contained disinfested clay soil and served as control. Five pots were used for each treatment. The plants were left to grow for three months after transplanting under greenhouse conditions (Fac. Agric., Cairo Univ.). The plants were examined for the severity of infection by the tested fungus monthly as mentioned under disease assessment and the averages were recorded. The pots were irrigated when it was necessary and fertilized with recommended doses as recommended by Min. of Agric. and Land Reclamation.

\subsection{Isolation, Purification and Identification of the Antagonists}

Rhizosheric soil samples collected from sweet pepper plants have severe infection by wilt (grown at Kalubia governorate) were used to isolate the antagonists. Serial dilution plate technique was used to isolate and select native Bacillus spp. on nutrient agar medium (Oedjijono and Dragar, 1993).The isolated bacteria were purified and identified depending on the description of Parry et al. (1983) and Holt and Krieg (1984). The identification was confirmed by the Biolog-System technique (Biological control of faba bean chocolate spot disease project, Plant Pathol. Res. Instit., A.R.C., Giza, Egypt)

\subsection{Effect of the Culture Filtrate on the Radial Growth}

The effect of the culture filtrate of five isolates of Bacillus spp. on the radial growth of $F$. o. f.sp. capsici was studied. One hundred $\mathrm{ml}$. of nutrient medium were put in 
each $250 \mathrm{ml}$ flask and sterilized by steamer for three successive days. The medium was inoculated with a loop of the bacterial bioagents taken from two day-old culture. Inoculated flasks were incubated on a rotary shaker at 200 rpm for 2 days at $30 \pm 2{ }^{\circ} \mathrm{C}$. The culture filtrate was filtered through Whatman No.1 filter paper and the filtrate was collected in a flask. The culture filtrate of the bioagents was mixed with the component of PDA medium in different proportion $(20,40,60$ and $80 \%)$. The medium was then sterilized and poured into the Petri-dishes $(20 \mathrm{ml} /$ plate $)$. After solidification the Petri plates were inoculated with 5 $\mathrm{mm}$. discs of the test pathogen cut from the five days old culture. PDA plates inoculated with the test pathogen, but not amended with the culture filtrate of Bacillus spp. were maintained as control. Plates were then incubated in an incubator at $30 \pm 2^{\circ} \mathrm{C}$. Five replications were maintained for each treatment. The radial growth was measured when the plates of the control treatment covered with the fungal growth. Inhibition percentage of mycelial growth of the tested pathogen was calculated by the formula:

$$
\mathrm{I}=(\mathrm{C}-\mathrm{T}) / \mathrm{C} \text { X100 }
$$

Where;

$\mathrm{I}=$ Percent of inhibition in growth of the tested pathogen, $\mathrm{C}=$ Radial growth of the pathogen $(\mathrm{mm})$ in control, $\mathrm{T}=$ Radial growth of the pathogen $(\mathrm{mm})$ in treatment.

\subsection{Effect on Wilt Severity and some Crop Parameters}

Ten seeds (Balady cv.) were surface sterilized with $1.0 \%$ solution of sodium hypochlorite for $1 \mathrm{~min}$ and then thoroughly washed with tap water. Seeds were sown in plots $(70 \times 30 \times 40 \mathrm{~cm}$.) containing formalin sterilized clay soil and kept under greenhouse conditions. When the seedlings were of 3 weeks old, they were thinned into four seedlings in each plot and one week later they received the following treatments:

1 The seedlings supplied with the bacterial suspension of B.pumilus at the rate of $500 \mathrm{ml}\left(1 \times 10^{3} \mathrm{cfu}\right) /$ plot.

2 The seedlings supplied with the bacterial suspension of B.subtilis at the rate of $500 \mathrm{ml}\left(1 \times 10^{3} \mathrm{cfu}\right) /$ plot.

3 The seedlings supplied with the bacterial suspension of $B$. thuringiensis at the rate of $500 \mathrm{ml}\left(1 \times 10^{3} \mathrm{cfu}\right) /$ plot.

4 The seedlings supplied with the bacterial suspension of B.pumilus at the rate of $500 \mathrm{ml}(1 \times 103 \mathrm{cfu}) /$ plot, two weeks before infestation with FOC .

5 The seedlings supplied with the bacterial suspension of B.subtilis at the rate of $500 \mathrm{ml}\left(1 \times 10^{3} \mathrm{cfu}\right) /$ plot, two weeks before infestation with FOC.

6 The seedlings supplied with the bacterial suspension of $B$. thuringiensisat the rate of $500 \mathrm{ml}\left(1 \times 10^{3} \mathrm{cfu}\right) /$ plot, two weeks before infestation with FOC.

7 The seedlings left to grow without supplying with any additional from Bacillus spp., but received $500 \mathrm{ml}$ water only (control uninfested soil).

8 The seedlings left to grow without supplying with any additional from Bacillus spp., but infested with the spore suspension of the causal fungus at the rate of $500 \mathrm{ml}\left(1 \times 10^{3}\right.$ conidia $) /$ pot.

After another three weeks the grown sweet pepper plants received the previous treatments. Six plots were used for each treatment, where three plots were used to assess disease severity and the three others for estimation of plant height $(\mathrm{cm})$ the number and weight of pods / plant.

\subsection{Disease Assessment}

Disease severity was assessed four months after sowing or three months after transplanting using the devised scale (0 to 5 ) by Amini and Sidovich (2010) on the foliage growth using the following scale:

Where:

$0=$ No foliar symptoms,

$1=$ Chlorosis and/or wilt restricted to cotyledons or first leaf,

$2=$ Chlorosis and/or wilt extending beyond the first leaf,

3 = Moderate to severe foliar symptoms usually with some abscised leaves,

$4=$ Severe foliar symptoms on the entire plant, and

$5=$ Dead plant.

Disease severity on foliage growth $\%=£(n x v) / 5$ N X 100

Where:

$\mathrm{n}=$ Number of infected leaves in each category.

$\mathrm{v}=$ Numerical values of each category.

$\mathrm{N}=$ Total number of the infected leaves.

The plants were also rated for vascular discoloration using the devised scale (0-5) by Ulloa et al.(2006) using the following scale:

Where:

0 = No discoloration,

$1=$ Light discoloration evident as spotty areas in the crosssection of the stem,

$2=$ More continuous discoloration covering an area between one quarter and one half of the cross-section stem but light in color,

$3=$ Vascular discoloration (moderate in color) evident in a band encircling almost the entire stem cross-section,

4 = Vascular discoloration darker in color than in 1 or 2 , and evident across most of the vascular tissue in a cross section of the stem, and

$5=$ Plant severely damaged, vascular discoloration evident throughout cross-section of the stem.

Disease severity on the vascular $\%=£(n x v) / 5$ N X 100

Where:

$\mathrm{n}=$ Number of infected vascular in each category.

$\mathrm{v}=$ Numerical values of each category.

$\mathrm{N}=$ Total number of the infected vascular.

Also, plant height $(\mathrm{cm})$ of the grown plants, the average No. of pods / plant and weight of pods (g) / plant were assessed and recorded. 


\subsection{Estimation of Total Phenolic Compounds}

One gram of sweet pepper leaves sample was extracted with $10 \mathrm{ml}$ of $80 \%$ methanol at $70{ }^{\circ} \mathrm{C}$ for $15 \mathrm{~min}$. Reaction mixture was containing $1 \mathrm{ml}$ of methanolic extracts, $5 \mathrm{ml}$ of distilled sterilized water, and $250 \mu \mathrm{l}$ of Folin-Ciocalteau reagent $(1 \mathrm{~N})$. This solution was kept at $25{ }^{\circ} \mathrm{C}$. The absorbance of the developed blue color was measured using a spectrophotometer at $725 \mathrm{~nm}$. Gallic acid was used as the standard. The amount of phenolic composunds was expressed as mg gallic acid per g plant material (Zieslin and Ben-Zaken, 1993).

\subsection{Statistical Analysis}

Data were statistically analyzed using the standard procedures for complete randomize block and split designs as mentioned by Snedecor and Cochran (1967). The averages were compared at 5\% level using least significant differences (L.S.D) according to Fisher (1948).

\section{Results}

\subsection{Isolation, Purification and Identification of the Associated Fungi}

Isolation trials from sweet pepper plants (Balady cv.) showing characteristic symptoms of wilt collected from Dakahlia, Menofia, Kalubia and Giza governorates yielded many fungal isolates. The isolated fungi were purified and identified as : Alternariaspp., Fusarium oxysporum, Pythium spp., Rhizontonia solani, Sclerotium rolfsii and Trichoderma spp.

The isolates of the fungus $F$. oxysporum were selected and tested for their pathogenicity and the most virulent isolate was chosen.

\section{1 .Pathogenicity Test of the Four Isolates of F. oxysporum}

Pathogenicity test of the four isolates of $F$. oxysporum (Table 1) reveals that the four tested isolates were pathogenic to sweet pepper plants and showing typical wilt symptoms on the foliage growth and the xylem vesicles. Data indicate that the fungus was more virulent when the seeds were used than using of the transplants in this experiment. In addition, the symptom of the disease was obvious on both the foliage growth and the xylem vesicles. Furthermore, the isolate of Kalubia governorate of the fungus $F$. oxysporum was the highest virulent one either on the foliage growth and the xylem vesicles. Therefore, it was used in the following experiments. Also, testing of cucumber ( Amira cv), eggplant ( Balady black cv.), sweet pepper ( Balady cv.), strawberry ( Camarosa cv.), tomato ( GS cv.) and water melon ( Giza 1 cv.) to their susceptibility to the infection by $F$. oxysporum indicated that the highest infection by the fungus was occurred only on sweet pepper and low infection was found in case of the other plants. Therefore, the fungus $F$. oxysporum named Fusarium oxysporum f.sp. capsici.

Table 1. Pathogenicity test of the four isolates of F. oxysporum using seeds and transplants of sweet pepper (Balady cv.), greenhouse experiments.

\begin{tabular}{|c|c|c|c|c|c|c|}
\hline \multirow{4}{*}{ Isolates } & \multicolumn{3}{|c|}{$\%$} & \multicolumn{2}{|c|}{$\%$} & \multirow{4}{*}{ Mean } \\
\hline & \multicolumn{2}{|c|}{ Disease severity of sown seeds on the } & \multirow{3}{*}{ Mean } & \multicolumn{2}{|c|}{ Disease severity of transplanting on the } & \\
\hline & Foliage & Xylem & & Foliage & Xylem & \\
\hline & Growth & vesicles & & growth & vesicles & \\
\hline Dakahlia & 36.8 & 42.1 & 39.5 & 32.4 & 40.2 & 33.3 \\
\hline Menofia & 40.8 & 45.7 & 43.3 & 39.0 & 41.4 & 40.2 \\
\hline Kalubia & 45.8 & 52.5 & 49.2 & 42.8 & 50.3 & 46.6 \\
\hline Giza & 42.3 & 50.8 & 46.5 & 40.2 & 47.8 & 44.0 \\
\hline Control & 0.0 & 0.0 & 0.0 & 0.0 & 0.0 & 0.0 \\
\hline Mean & 33.1 & 38.2 & ----- & 30.9 & 35.9 & ---- \\
\hline
\end{tabular}

\subsection{Effect of Culture Filtrate of Five Bacillus Strains on the Radial Growth of F. o.f.sp. Capsic}

Table 2. Effect of culture filtrate of five Bacillus strains on the radial growth of F. o.f.sp. capsici, five days after incubation at $30 \pm^{\circ} C$.

\begin{tabular}{lccccc}
\hline \multirow{2}{*}{ Bacillus strains } & \multicolumn{7}{c}{ Average radial growth (mm) at concentration of } \\
\cline { 2 - 6 } & $\mathbf{2 0}$ & $\mathbf{4 0}$ & $\mathbf{6 0}$ & $\mathbf{8 0}$ & Mean \\
\hline B.chitinosporus & 76.8 & 50.0 & 32.2 & 12.0 & 32.8 \\
B. coagulans & 79.6 & 56.8 & 43.0 & 29.4 & 52.2 \\
B.pumilus & 74.4 & 47.2 & 29.0 & 10.8 & 40.4 \\
B.subtilis & 70.6 & 35.0 & 0.0 & 0.0 & 26.3 \\
B.Thuringiensis & 66.4 & 30.2 & 0.0 & 0.0 & 24.2 \\
Control & 90.0 & 90.0 & 90.0 & 90.0 & 90.0 \\
Mean & 76.3 & 61.8 & 38.8 & 28.4 & \\
\hline
\end{tabular}

L.S.D. at $5 \%$ for: Bacillus strains $(B)=2,3$, Concentration $(C)=1.8$ and $B$ $\mathrm{x} C=3.1$.
Data presented in Table (2) reveal that all the five Bacillus strains caused significant reduction to the radial growth of F.o.f.sp.capsici compared with control treatment. This reduction was gradually increased by increasing the concentration of the tested bioagents. In addition, the growth of the tested pathogen was completely inhibited by B.subtilis and B.thuringiensis at the concentration of $60 \%$. Furthermore, B.thuringiensis was the most efficient bioagent in this regard followed by B.subtilis then B.pumilus, being $24.2,26.3$ and $32.8 \mathrm{~mm}$, respectively. Therefore, they were chosen to test their capability to the biocontrol of the tested pathogen under greenhouse conditions. Meanwhile, B. coagulans was the lowest efficient one in this regard $(52.2 \mathrm{~mm})$. 


\subsection{Effect of Three Bacterial Bioagents on the Severity of Pepper wilt as Well as some Crop Parameters}

Table (3) shows that no symptoms of the disease were observed on the foliage growth and the roots of the plants in case of infestation the soil with the bacterial strains, i.e. B.pumilus,.B.subtilis and B. Thuringiensis as well as control treatment (uninfested soil). In addition. the three tested bioagents resulted in significant reduction to sweet pepper wilt with significant increase to the plant height as well as the number of pods and their weight / plant when added to the soil infested with the causal pathogen compared with infestation with the causal pathogen only. The symptoms of the disease were obvious both on the foliage growth and the vascular (xylem vesicles), but the severity of the disease was more higher on the xylem vesicles than on the foliage growth, being 10.5 and $13.0 \%$, respectively. In addition, plants grown in soil infested with Bacillus strains were of high values of plant height and fruit yield ( number and weight / plant ) than that grow in the control (uninfested soil).

Table 3. Effect of some bacterial bioagents on the severity of sweet pepper wilt as well as plant height and the produced pod yield / plant, greenhouse experiment.

\begin{tabular}{|c|c|c|c|c|c|c|}
\hline \multirow{2}{*}{ Treatments } & \multicolumn{2}{|c|}{ \%Disease severity on } & \multirow{2}{*}{ Mean } & \multirow{2}{*}{ Plant height(cm) } & \multirow{2}{*}{$\begin{array}{c}\text { Average No. of } \\
\text { pods / plant }\end{array}$} & \multirow{2}{*}{$\begin{array}{l}\text { Average weight of } \\
\text { pods (g) / plant }\end{array}$} \\
\hline & Foliage growth & Xylem vesicles & & & & \\
\hline B.pumilus (BP) & 0.0 & 0.0 & 0.0 & 79.7 & 38.2 & 1161.6 \\
\hline B.subtilis (BS) & 0.0 & 0.0 & 0.0 & 82.3 & 39.6 & 1218.0 \\
\hline B.thuringiensis (BT) & 0.0 & 0.0 & 0.0 & 95.9 & 42.0 & 1371.1 \\
\hline F.o.capsici (FOC) & 63.9 & 71.8 & 67.9 & 36.1 & 20.0 & 369.9 \\
\hline $\mathrm{BP}+\mathrm{FOC}$ & 8.6 & 12.7 & 10.7 & 64.0 & 33.4 & 918.4 \\
\hline $\mathrm{BS}+\mathrm{FOC}$ & 7.4 & 11.0 & 9.2 & 67.5 & 33.8 & 932.2 \\
\hline $\mathrm{BT}+\mathrm{FOC}$ & 4.2 & 8.5 & 6.4 & 71.0 & 45.0 & 990.5 \\
\hline $\begin{array}{l}\text { Control } \\
\text { ( Uninfested ) }\end{array}$ & 0.0 & 0.0 & 0.0 & 68.8 & 32.0 & 900.0 \\
\hline Mean & 10.5 & 13.0 & ------- & LSD at $5 \%=2.2$ & LSD at $5 \%=1.8$ & LSD at $5 \%=12.3$ \\
\hline
\end{tabular}

LSD at $5 \%$ for: Treatments $(T)=3.0$, Disease severity $(\mathrm{D})=2.1$ and $\mathrm{TxD}=3.9$.

\subsection{Changes in the Content of Total Phenolic Compounds}

Induction of defense-related biochemicals like total phenolic compounds was studied in bacterial- and pathogen-treated sweet pepper plants under different combinations (Table 4). It was noticed that Bacillus strains induced considerable higher production of phenolic compounds compared with control treatment and F.o. f.sp. capsici. However, low change was observed in pathogenic control whereas no great change was observed in total phenolic contents of untreated control ( $0.46 \mathrm{mg}$ gallic acid / $\mathrm{g}$ plant fresh leaves). A great increase was observed in the total phenolic compounds of plants treated with $B$. thuringiensis, either alone or in combination with the causal pathogen, being 0.60 and $0.66 \mathrm{mg}$ gallic acid / g plant fresh leaves, respectively.

Table 4. Effect of bacterial- and pathogen-treated sweet pepper plants under different combinations on the content of phenolic compounds, 15 and 30 days after inoculation with the bioagents and the pathogen.

\begin{tabular}{lcccc}
\hline \multirow{2}{*}{ Treatments } & \multicolumn{3}{c}{ Gallic acid in mg / g plant leaves } \\
& \multicolumn{3}{c}{ after (days) } & \multirow{2}{*}{ Mean } \\
\cline { 2 - 4 } & $\mathbf{0 . 0}$ & $\mathbf{1 5}$ & $\mathbf{3 0}$ & \\
\hline B.pumilus (BP) & 0.40 & 0.54 & 0.56 & 0.50 \\
B.subtilis (BS) & 0.40 & 0.56 & 0.59 & 0.52 \\
B.thuringiensis (BT) & 0.40 & 0.68 & 0.72 & 0.60 \\
F.o.capsici (FOC) & 0.40 & 0.48 & 0.50 & 0.46 \\
BP + FOC & 0.40 & 0.65 & 0.68 & 0.58 \\
BS + FOC & 0.40 & 0.68 & 0.71 & 0.60 \\
BT + FOC & 0.40 & 0.78 & 0.83 & 0.66 \\
Control & 0.40 & 0.41 & 0.42 & 0.41 \\
(Uninfested ) & 0.40 & 0.60 & 0.63 & ------ \\
Mean & & & & \\
\hline
\end{tabular}

\section{Discussion}

F. oxysporum is a soil-borne in nature and invades vascular system of a plant internally. It is better to protect the entrance point of this fungus in plant instead of changing the entire soil mycoflora. For this purpose, some microorganisms can be used to induce resistance in plants for combating with this devastating pathogen (Akram et al.,2013).

The isolates of the fungus $F$. oxysporum were selected and tested for their pathogenicity and chosen the most virulent isolate. The highest infection by the fungus was occurred only on sweet pepper and low infection was found in case of the other four tested plants. Therefore, the fungus $F$. oxysporum has the name of Fusarium oxysporum f.sp. capsici.. The isolated fungi were previously isolated by Abada(1994).

It has been found that all the five Bacillus strains caused significant reduction to the radial growth of F.o.f.sp. capsici compared with control treatment. This reduction was gradually increased by increasing the concentration of the tested bioagents. In addition, the growth of the tested pathogen was completely inhibited by B.subtilis and B.thuringiensis at the concentration of $60 \%$. Furthermore, B.thuringiensis was the most efficient bioagent in this regard followed by B.subtilis then B.pumilus, respectively.

The three tested bioagents resulted in significant reduction to sweet pepper wilt with significant increase to plant height as well as the number of pods and their weight compared with control treatment. The symptoms of the disease were obvious both on the foliage growth and the 
vasculr, but the severity of the disease was more higher on the xylem vesicles (vasculr) than on the foliage growth, being 10.5 and $13.0 \%$, respectively. In addition, plants grown in soil infested with Bacillus strains were of high values of plant height and fruit yield (number and weight / plant) than that grown in the control (uninfested soil).

Colonization of plant roots by selected strains of nonpathogenic bacteria, such as various species of the genus Bacillus (Kloepper et al., 2004) can induce a distinct broadspectrum resistance response in both below- and aboveground parts of the plant. This type of resistance to diseases is named as induced systemic resistance (ISR) (van Loon et al., 1998; van Loon,2007 and De Vleesschauweret al.,2009). The fungus Fusarium oxysporum is one of soil-borne plant pathogens and is widely distributed in various soil types worldwide. Recently, there has been a growing interest in nonpathogenic bacteria due to their efficacy as bioagents in many crops (Kloepper et al., 2004; Yu and Chengxiang , 2011; Akram et al., 2013; Zaher et al., 2013 and Abada and Eid, 2014). Application of some Bacillus strains to the seedlings has been found effective for suppressing soil borne diseases and has successfully induced systemic resistance in the treated plants (Kloepper et al., 2004 and Szczech and Shoda, 2007). Elicitation of ISR by Bacillus strains has been demonstrated in greenhouse or field trials on tomato, bell pepper, muskmelon, watermelon, sugar beet, tobacco, Arabidopsis sp., cucumber, loblolly pine, and two tropical crops (Kloepper et al., 2004).

Xinget al.(2003) mentioned that Bacillus sp. grow very fast and occupies the court of infection and preventing pathogen spores to reach susceptible tissues in competition for spaces. This might be due to that treatments with biopreparation induce systemic resistance as the main mechanism of activity on the plant. Also, Jacobsen et al.(2004) and $\mathrm{Yu}$ et al. (2011) reported that B. subtilis CAS15 has great potential for plant growth promotion and biological control, where reduced the incidence of Fusarium wilt in pepper significantly, by $12.5-56.9 \%$ due to induced systemic resistance .They added that there were significant increases in plant height also enhanced the yield of pepper by shortening the time to 50 percent flowering to 17.26 days, increasing the average fruit weight $36.92 \%$, and increasing the average yield per plant $49.68 \%$. This research showed that $B$. subtilisCAS15 has great potential for plant growth promotion and biological control.

It is supposed that Bacillus spp. could be have diverse plant response involved in synthesis and accumulation of antimicrobial phytoalexins (Hammond-Kosack and Jones, 1996), induction of hypersensitive response ( $\mathrm{He}$ et al.,1993), production of defense-related proteins (Yu,1995) production of activated oxygen species (Bakeret al.,1993), and modify-cation of plant cell wall by deposition of callose (Veit et al.,2001).

Protection of plants from disease by induction of systemic resistance is a new approach. This is much less harmful to the environment as compared to deadly agrochemicals applied to control plant diseases.
Phenolic content is the compounds whose quantity is raised when a plant comes under attack by a pathogen (Van Peeret al.,1991 and Waterman and Mole, 1995). Systemic induction of phenolic compounds under influence of bacterial strains was first reported by Van Peer et al. (1991). However, this alone is not reliable for indication of disease resistance in plant tissues (Waterman and Mole, 1995). Akram et al. (2013) reported that a significant increase in total phenolic contents was observed in bacterial-treated plants. They added that pathogen alone was able to induce phenolic formation in plants but with slightly increased levels. It was noticed that Bacillus strains induced considerable higher production of phenolic compounds compared with control treatment and F.o.f.sp. capsici. However, low change was observed in pathogenic control, whereas no great change was observed in total phenolic contents of untreated control. On the other hand, a great increase was observed in the total phenolic compounds of plants treated with $B$. thuringiensis, either alone or in combination with the causal pathogen.

\section{References}

[1] Abada K.A.(1994). Fungi associated with root-rot of pepper and some factors affecting disease incidence. 7 th Cong. of Phytopathol., April, Cairo, Egypt,:219-226 .

[2] Abada K.A. and Eid Kh. E. ( 2014). A Protocol suggested for management of canta-loupe downy mildew . American Journal of Life Sciences, 2(3):1-10.

[3] Attia M.F. and Abada K.A. (1994) . Control of wilt and root-rot of pepper. $7^{\text {th }}$ Cong. of Phytopathol., April, Cairo, Egypt: 397-409.

[4] Akram ,W.; Mahboob A. and Javel A.A.(2013). Bacillus thuringiensis strain 199 can induce systemic resistance in tomato against Fusarium wilt .Europ.J.of Mirobiol. and Immunol., 275-280.

[5] Amini J. and Sidovich, D. F. (2010). The effects of fungicides on Fusarium oxysporum f. sp. lycopersici associated with Fusarium wilt of tomato. J. of Plant Protec.Res., 50 (2), 175-180.

[6] Albersheim P. and Valent B.S.(1978). Host-pathogen interactions in plants. Plants, when exposed to oligosaccharides of fungal origin, defend themselves by accumulating antibiotics. J. Cell Biol., 78(3):627-643.

[7] Albersheim P. and Anderson-Prouty A.J.(1975). Carbohydrates, proteins, cell surfaces, and the biochemistry of pathogenesis. Ann. Rev. Plant Physiol., 26: 31-52.

[8] Baker C.J.; Orlandi E.W. and Mock N.M.(1993). Harpin, an elicitor of the hypersensitive response in tobacco caused by Erwinia amylovora, elicits active oxygen production in suspension cells. Plant Physiol.,102(4):1341-1344.

[9] BlackL.; Green, S.; Hartman, G. and Poulos J. (1991). Pepper Diseases: A Field Guide. Publication No. 91-347. Asian Vegetable Research and Development Center. P.O. Box 205, Taipei 10099. 98pp. 
[10] Brewer M.T. and Larkin R.P. (2005). Efficacy of several potential biocontrol organisms against Rhizoctonia solani on potato. Crop Protection, 24: 939-950.

[11] Booth C.(1971). The genus Fusarium. Commonwealth Mycological Institute, Kew, Surrey, England.

[12] De Vleesschauwer D. and Hofte M.. (2009). Rhizobacteria-induced systemic resistance. Adv. Bot. Res.,;51:223-281.

[13] Domsch K.H.; Gams W. and Anderson T.H. (1980). Compendium of Soil Fungi. Vol. 1 and 2, Academic press. London.

[14] Fisher R.A., 1948. Statistical Methods $6^{\text {th }}$ ed. Iowa State Univ. Press, Ames, Iowa, USA.

[15] Hammond-Kosack K.E. and Jones J.D.(1996). Resistance gene-dependent plant defense responses. Plant Cell,8 (10): $1773-1791$

[16] He S.Y.; Huang H.C. and Collmer A.(1993 ). Pseudomonas syringae pv. syringae harpin Pss: a protein that is secreted via the Hrp pathway and elicits the hypersensitive response in plants. Cell.,73(7):1255-1266.

[17] Holt J.G. and Krieg N.R(1984). Bergey's Manual of Systematic Bacteriology. Williams \& Wilkins, Baltimore, USA.

[18] Jacobsen B. J., Zidack, N. K. and Larson B. J. 2004. The role of Bacillus-based biological control agents in integrated pest management systems: Plant diseases. Phytopathology,94:1272-1275.

[19] Kloepper J.W.; Ryu C.M. Zhang S.(2004). Induced systemic resistance and promotion of plant growth by Bacillus spp. Phytopathology,94(11):1259-1266.

[20] Oedjijono M. A. L. and Dragar C. (1993). Isolation of bacteria antagonistic to a range of plant pathogenic fungi. Soil Biol. Biochem., 25: 247-250.

[21] Parry J.M.; P.C.B. Turnbull and J.R. Gibson (1983). A colour atlas of Bacillus species, Wolfe Medical Publications Ltd.

[22] Snedecor G.W. and Cochran W.G. 1967. Statistical Methods. $6^{\text {th }}$ Ed. Iowa State. Univ. Press, Ames, Iowa, USA.

[23] Szczech M. and Shoda M. (2006). The effect of mode of application of Bacillus subtilis RB14-C on its efficacy as a biocontrol agent against Rhizoctonia solani. J Phytopathol.,154:370-377.

[24] Ulloa M.;; Hutmacher R . B.; Davis R . M..; Wright S. D.; Percy R., and Marsh B. (2006).Breeding for Fusarium wilt race 4 resistance in cotton under field and greenhouse conditions. The J. of Cotton Sci., 10:114-127.

[25] van Loon L.C.; Bakker P.A. and Pieterse C.M..(1998). Systemic resistance induced by rhizosphere bacteria. Ann. Rev. Phytopathol., 36:453-483.

[26] Van Loon L.C. (2007).Plant responses to plant growthpromoting rhizobacteria. Eur. J. Plant Pathol., 119:243-254.

[27] Van Peer R.; Niemann G.N. and Schippers B.(1991). Induced resistance and phytoalexin accumulation in biological control of Fusarium wilt in carnation by Pseudomonas sp. strain WCS417r. Phytopathology,81:728734 .

[28] Veit S.; Wörle J.M.; Nürnberger T.; Koch W. and Seitz H.U.(2001). A novel protein elicitor (PaNie) from Pythium aphanidermatum induces multiple defense responses in carrot, Arabidopsis, and tobacco. Plant Physiol.,127(3):832841.

[29] Waterman P.G. and Mole S. (1994).Analysis of Phenolic Plant Metabolites. London: Blackwell Sci. Publ., Method in Ecology.

[30] Xing L.; Ding Z.; Wenxiang Y.;. Li D and Daqun L. (2003). A study on the effect ofBacillus on downy mildew of cucumber. Plant Protection, 29(4): 25-27.

[31] Yu L.M.(1995). Elicitins from Phytophthora and basic resistance in tobacco. Proc. Natl. Acad. Sci. U S A., 92(10):4088-4094.

[32] Yu X.; Ai C. ; Xin L.and Zhou G.(2011).The siderophoreproducing bacterium, Bacillus subtilis CAS15, has a biocontrol effect on Fusarium wilt and promotes the growth of pepper. Eur. J. Soil Biol.,47(2):138-145.

[33] Zaher,Effat A., Abada , K.A. and Zyton,Marwa A. (2013).Effect of combination between bioagents and solarization on management of crown-and stem-rot of Egyptian clover. J.of Plant Sci.,1 ( 3):43 -50 .

[34] Zieslin N. and Ben-Zaken R.(1993). Peroxidase activity and presence of phenolic substances in peduncles of rose flowers. Plant Physiol. Biochem.,31:333-339. 